\title{
DETERMINANTS OF CHOICE OF CROP VARIETY AS CLIMATE CHANGE ADAPTATION OPTION IN ARID REGIONS OF ZIMBABWE
}

\author{
James Zivanomoyo, Researcher \\ Department of Economics, Great Zimbabwe University, Zimbabwe \\ E-mail: uzbelt@gmail.com \\ Julius Mukarati, Researcher \\ Department of Agricultural Economics, Midlands State University, Zimbabwe
}

\begin{abstract}
Impacts of climate change in developing countries remain poorly understood because few studies have successfully analyses the overall impact of climate on developing country economies. Agricultural growth is widely viewed as an effective and most important way to reduce poverty in developing countries which are hardly hit by the adverse effects of climate change (Datt and Ravallion, 1996). Despite this knowledge the main challenge is how to increase agricultural productivity to improve household welfare and increase food security in these changing and challenging climatic conditions. This study used the multinomial logit model to analyse the determinants of farmers' choice of crop variety in the face of climate change. The estimation of the multinomial logit was done by using the sorghum variety options as dependent variable and where farmers grow other crop different from sorghum as the reference state. Results show that the key determinants of choosing crop variety are; the price of existing crop variety, level of education of farmers, the size of the farms, government policies and incentives and credit availability.
\end{abstract}

\section{KEY WORDS}

Climate change; Arid regions; Biotic; Drought resistant crops; Multinomial logit.

Climate change is change in the numerical distribution of weather around an average over periods of time that range from decades to millions of years (Wigley, 1999; McCarthy, et al., 2001; IPCC, 2007a). Climate change may be limited to a specific region or may occur across policy, climate change usually refers to changes in modern climate which is sometimes qualified as anthropogenic or human induced climate change or "Global Warming" (Wigley, 1999; USAID, 2007; Biermann, 2007).

Empirical evidence (IPCC, 2007b; Assan and Kumar, 2009) shows that climate change and environmental variability is emerging as one of the most important challenges of the $21 \mathrm{st}$ century. World bank (2003) also notes that frequency of heavy precipitation events has increased over most land areas and widespread changes in extreme temperatures has been recorded over the last 50 years. These recent trends, according to World Bank (2003), show a tendency towards greater extremes where arid or semi-arid areas especially in northern, western, eastern and parts of southern Africa will become steadily drier, with increased magnitude and variability of precipitations and storms. Climate science contends that even if all anthropogenic greenhouse gas emissions ceased immediately, the world would still experience substantial climate change (IPCC, 2007a; JNCC, 2008).

Climate change affects agriculture and food production in complex ways (IPCC, 2007b; Hassan and Nhemachena, 2008; Dinar et al, 2008). It affects food production directly through changes in agro-ecological conditions and indirectly by influencing growth and distribution of incomes, and thus demand for agricultural products. Since the agriculture sector is the backbone of many developing country economies, decreased output in the sector will have negative impact on the overall economic performance.

Numerous partial equilibrium studies have assessed the micro impacts of climate change on agriculture in developing countries (Deressa 2007, Deressa and Hassan 2009, Hassan and Nhemachena 2008). Though extensive research and empirical work exists on the impact of climate change on agriculture, there is limited focus on the literature review of 
impact of climate change on the overall economy. There is need for a detailed review of literature and the methods of measuring the impact of climate change on the economy.

Many arid regions of Africa are already experiencing unpredictable weather, with more frequent droughts, floods, and strong winds being experienced. Africa in particular, is susceptible to climate change and the main reasons include: over reliance on rain-fed agriculture and other activities that are highly weather-sensitive; inadequate water supply, and degradation of many of its natural resources. Rapid population growth, inadequate basic infrastructure, and weakening social institutions and safety nets only increase its susceptibility to variations and changes in climate, threatening to undo decades of poverty reduction and development achievements. Given that about $80 \%$ of the African countries regions are classified as Arid and Semi-Arid, climate change poses new other threats to water availability, agriculture and food security, human and animal health, biodiversity, transport and tourism among others.

While on one hand, climate has always dictated the kind of crops that people grow or livestock that people rear, activities of human-kind, on the other hand have over the last two centuries become a key determinant of climate on a global scale (IPCC, 2007b). The climatic parameters that influence the socioeconomic prospects and problems are the annual rainfall (its spatial and temporal distribution) and temperature fluctuations. Some of the socioeconomic problems emanating from climate related factors have manifested themselves in sectors such as arable agriculture (both rain-fed and irrigated); livestock production, energy sector, wildlife sector and health sector among others. This may led to the problems of desertification, food insecurity, low hydroelectric power production during drought season; and decimation of livestock through recurrent droughts.

Increased temperatures are likely to exacerbate the drought conditions already experienced and may in future have significant effect on water and food availability. More unpredictability in seasonal rainfall has caused an increase in short heavy rainfall periods leading to flooding, landslides and water pollution which may be worse during coming years. Increased incidences of drought and persistent susceptibility of the rural poor to the variations and change in climate has posed serious threat not only on the capacity of poverty-reduction initiatives but also on agricultural production activities and food security, especially in the arid and semi-arid regions.

Agricultural growth is widely viewed as an effective and most important way to reduce poverty in developing countries which are hardly hit by the adverse effects of climate change (Datt and Ravallion, 1996). Despite this knowledge the main challenge is how to increase agricultural productivity to improve household welfare and increase food security in these changing and challenging climatic conditions. Area expansion and irrigation have become a minimal source of output growth, thus growth will depend more on adoption of yield increasing varieties and crop/variety diversification (Hossain, 1989). Agriculture productivity can only come from growth in yields from adoption of new improved crop varieties from agricultural technology. Agricultural technology can be an important factor for improving household welfare in rural areas in the face of frequent droughts due to climate change and, the adoption of the new crop varieties can leads to increased agricultural productivity. Increased productivity can help reduce poverty by increasing farmers' income, reducing food prices and therefore enhancing increments in consumption (Diagne et al., 2009). To increase agricultural productivity rural household must adopt the new improved crop varieties which mature early and are drought tolerant. The benefits of these crop improvement technologies depend on household adoption patterns which are influenced by different socio-economic and farm type factors. Thus, the impact of new crop varieties will be affected by both local conditions and household characteristics.

Though the new crop variety can improve productivity, food and crop resilience cannot be guaranteed because these varieties are susceptible to pests and disease compared to the traditional varieties. Climate change affects both the biotic and abiotic factors of crop systems that threaten crop sustainability and production conditions (Matson et al, .1997). To buffer crop production from the effects of greater climate variability and extreme events, variety diversification is the most rational and cost effective method. Many agricultural based 
economies have few other livelihoods strategies (Tilman et al,. 2002), thus the development of resilience agricultural systems through varieties diversification is essential since many communities depends on agriculture for livelihoods (Altieri, 1999). In Africa many small farms have little capital to invest in expensive adaptation strategies and pests and disease control mechanisms, hence they are more vulnerable to food insecurity. Farmers can promote natural barriers to diseases and pests and increase production stability through crop varieties diversification.

Food insecurity and poverty is widespread in rural Africa because of persistent crop failure due to increased frequency of drought. The proportion of people suffering from food insecurity is high in arid and semi-arid region because they lack the capacity to adapt to climate change. In this regard, various adaptations have been undertaken in these areas to improve crop productivity. However most of these strategies that have targeted water and soil management have failed to ascertain food security for rural households. In drought stricken areas the Zimbabwe government started promoting the development and adoption of crop varieties of small grain crops to increase household food supply. The aim was to improve the productivity of sorghum and millet in drier regions of the country. With the help of donors and research institutions, several improved crop varieties of different crops have been developed and disseminated to the farmers. In spite of these efforts, empirical studies proved that adoption of these crop varieties by rural farmers is still limited leading to reduced yield in drought prone areas. According to Sech (2008), the unavailability of new variety seeds is the major constraint to successful adoption in many rural areas. Thus in order to ascertain agriculture productivity and food security, access to seeds must increase to lead to higher yield (Dontsop-Nguezet et al., 2011). These new varieties are prone to diseases and pests thus to improve food and crop resilience there is need for diversification with the traditional crop varieties.

Though several research have attempted to analyse the impact of climate and factors affecting the choice of adaptation methods in crop, livestock and mixed crop livestock production systems in Africa (Maddison, 2006: Kurukulasuriya and Mendelsohn,2008; Seo and Mendelsohn, 2008; Hassan and Nhemachena, 2008), the determinants of farmers' choice of crop varieties have not been investigated in detail in Zimbabwe. The primary goal of this paper is to investigate the determinants of farmers' choice of crop variety in Chivi district. This district in Masvingo province is chosen because it represents an ideal arid region (region 5) in Zimbabwe.

\section{ANALYTICAL AND EMPIRICAL FRAMEWORK}

Smallholder farmer in arid regions may decide to grow a particular crop variety or practice a certain cropping pattern if the perceived utility is greater than from other choices available. Let $U_{j}$ and $U_{k}$ represent utility from two cropping choices, then random utility models are given by:

$$
U_{j}=\beta^{\prime} X_{i}+\varepsilon_{j} \text { and } U_{k}=\beta^{\prime} X_{i}+\varepsilon_{k},
$$

where : $X_{i}$ is a vector of explanatory variables; $\beta_{j}, \beta_{k}$ - represent estimation parameters and, $\varepsilon_{j}, \varepsilon_{k}$-represents error terms. Thus the farmer will decide to grow crop $j$ if perceived utility ( $\left.U_{i j}\right)$ is greater than from other cropping options $\left(U_{i k}\right)$. The probability that a household will grow crop variety $\mathrm{j}$ is given by:

$$
p\left(\beta_{j} X_{i}-\beta_{k} X_{k}+\varepsilon_{j}-\varepsilon_{k} \succ 0 / X\right)
$$

The study used the multinomial logit model to analyse the determinants of farmers' choice of crop variety in the face of climate change. The multinomial logit model is used 
because it allows the analysis of decisions across more than two categories and computationally simple (Tse, 1987). Let $y$ denote the choice of crop variety taking value $(1,2 \ldots ., j)$ and $x$ represents a set of conditional variables. The multinomial model response probabilities are given:

$$
P(y=j / x)=\frac{\exp \left(x \beta_{j}\right)}{\left(1+\sum_{i=1}^{j} \exp \left(x \beta_{i}\right)\right.}
$$

To calculate the expected change in probability of a particular crop variety, we calculate the marginal effects as follows:

$$
\partial p_{i} / \partial x_{k}=P_{j}\left(\beta_{j k}-\sum_{j=1}^{j-1} P_{j} \beta_{j k}\right)
$$

For this study, there are four main cropping patterns that are being practised in Chivi district: 1. No sorghum production; 2. Growing of traditional varieties; 3. Growing of new crop varieties; 4. Growing mixed varieties.

\section{DATA AND VARIABLES}

Data for this study was collected from both primary and secondary sources. While primary data was obtained from survey and interviewing households in Chivi District, secondary data was obtained from documentary reviews among institutional libraries.

\begin{tabular}{|c|c|c|}
\hline Variable & Description & Expected sign \\
\hline Agehh & Age of household head at the time of adoption & + or - \\
\hline Educa & Years of formal education of household head & + \\
\hline Farmsize & Farm size in acres at the time of adoption & + \\
\hline Credit & Accesss to credit facility & + \\
\hline Input price & $\begin{array}{l}\text { price of sorghum seeds variety at adoption } \\
\text { year } \$ / 10 \mathrm{~kg} \text { bag })\end{array}$ & - \\
\hline distance & Distance form input market $(\mathrm{km})$ & - \\
\hline Extension & $\begin{array}{l}\text { Farmer received information on new sorghum } \\
\text { variety at the first adoption }\end{array}$ & + \\
\hline
\end{tabular}

Table 1. Variables of research

A structured questionnaire was used to gather both qualitative and quantitative information covering aspects about climate change adaptation and sorghum varieties grown by farming households in Chivi District.

\section{RESULTS AND DISCUSSIONS}

The estimation of the multinomial logit was done by using the sorghum variety options as dependent variable and where farmers grow other crop different from sorghum as the reference state. The main problem of the multinomial logit results is that they only give the direction of the independent variables on the dependent variable and no actual magnitude of the probability. This study presented the marginal effects which measures the expected change in the probability of a particular choice. The chi2 statistics was highly significant ( $P$ $\prec 0,0000$ ) denoting a strong explanatory power of the model.

Education of household tend to decrease the probability of growing the traditional sorghum varieties and increase the probability of farmers to grow new sorghum varieties which are better adapted to drier conditions. A unit increase in years of schooling will result in 
about 52 percent decrease in traditional sorghum varieties production and a 5 percent change of growing new early maturing varieties.

Age of household head which represent farming experience influence the choice of sorghum varieties by farming household in Chivi district. Age of household head tend to decrease the probability of growing traditional sorghum varieties but increases the probability of growing new sorghum varieties. For instance, a unit increase in age result in 64 percent decrease in the probability of growing traditional varieties and a 5 percent increase in the probability of growing new sorghum varieties.

Table 2. Descriptive statistics

\begin{tabular}{|c|c|c|c|}
\hline Variable & Mean & Standard deviation & Percentage \\
\hline Agehh & 41,94 & 12.15 & - \\
\hline education & 1,35 & 1,23 & - \\
\hline Distance & 5,74 & 1,48 & - \\
\hline Credit & - & - & 92.34 \\
\hline Input price & 10.62 & 8.03 & - \\
\hline extension & - & - & 14,05 \\
\hline Farm size & 8.19 & 12.02 & - \\
\hline
\end{tabular}

Table 3. Results of multinomial logit model (marginal effects)

\begin{tabular}{|c|c|c|c|}
\hline variable & Traditional varieties & New varieties & Mixed varieties \\
\hline Agehh & $\begin{array}{c}-064754^{\star \star} \\
(-2,54)\end{array}$ & $\begin{array}{c}0,0531^{\star} \\
(1.10)\end{array}$ & $\begin{array}{l}0,0303 \\
(0,980)\end{array}$ \\
\hline education & $\begin{array}{c}-0,5264^{* * \star} \\
(-2,040)\end{array}$ & $\begin{array}{l}0,053^{*} \\
(1,71)\end{array}$ & $\begin{array}{c}0,0179 \\
(0,60)\end{array}$ \\
\hline distance & $\begin{array}{l}-0,0556 \\
(-0,39)\end{array}$ & $\begin{array}{l}0,242 \\
(1,07)\end{array}$ & $\begin{array}{l}0,582^{*} \\
(1,94)\end{array}$ \\
\hline Credit & $\begin{array}{c}0,203^{\star \star \star} \\
(3,54)\end{array}$ & $\begin{array}{c}0,1024^{*} \\
(1,88)\end{array}$ & $\begin{array}{l}0,018^{\star \star} \\
(2,58)\end{array}$ \\
\hline Input price & $\begin{array}{c}0,205^{\star \star \star} \\
(3,94)\end{array}$ & $\begin{array}{c}-0,155^{\star \star \star} \\
(2,75)\end{array}$ & $\begin{array}{c}-0,120^{*} \\
(1,76)\end{array}$ \\
\hline extension & $\begin{array}{l}0,080 \\
(0,55)\end{array}$ & $\begin{array}{l}-0,3260 \\
(-1,43)\end{array}$ & $\begin{array}{l}-3,318 \\
(-1,44)\end{array}$ \\
\hline Farm size & $\begin{array}{c}0,490^{\star \star \star} \\
(5,23)\end{array}$ & $\begin{array}{l}0,147^{*} \\
(1,98)\end{array}$ & $\begin{array}{l}0,065^{\star} \\
(2,44)\end{array}$ \\
\hline
\end{tabular}

Note: ${ }^{* *}$ denotes significance at $1 \%,{ }^{* *}$ denotes significance at $5 \%,{ }^{*}$ denotes significance at $10 \%$. Log likelihood =-137,10; Prob(chi2)=0,0000; LR chi2(32)=127,58; T-statistics in parenthesis.

Price of sorghum seeds significantly influences the probability of farmers to grow different sorghum varieties. Input price tends to increase the probability of growing traditional sorghum varieties which are ready available to farmers but tends to decrease the probability of growing new and mixed varieties. A unit increase in the price of sorghum seeds result in 21 percent increase in growing of traditional varieties and 15 percent decrease in probability of growing the new sorghum varieties. Since most of these rural farmers have limited income sources, increase in the price of sorghum render it unaffordable to most farmers thus the start to growing the traditional seeds from previous year's harvest.

The size of the farm owned by each household tends to influence the growing of both traditional and new sorghum varieties. A unit increase in farm size result in 49 percent increase in probability of growing traditional sorghum varieties, 15 and 6 percent increase in probability of growing new and mixed sorghum varieties respectively. This may be because when the farmers has large pieces of land they can afford to apportion the land and grow different varieties on these land apartment, thereby increasing the success rate of crops.

Availability of credit to farmers increases the probability of growing different sorghum varieties by farming households. Credit increases the probability of growing both the traditional and new sorghum varieties or even mixing the sorghum varieties. A unit increase prin credit facility to farmers lead to 20 percent increase in the probability of growing traditional sorghum varieties and 10 percent increase in the probability of growing new 
sorghum varieties. The credit facility to farmers will enable farmers to afford certified seeds of both traditional and new varieties which are highly productive. Thus when farmers have access to credit they can grow the traditional varieties or new varieties and be able to have increase yields.

\section{CONCLUSION AND RECOMMENDATIONS}

From the results of the study presented above, it is recommended that authorities in developing countries such as Zimbabwe should put in place policies design to increase educational standards of households. Educated and literate farmers are less resistant to change. The price of small grain such as sorghum inputs plays a significant role in encouraging the introduction of new crop varieties. This implies that the price elasticity of demand for sorghum seed is elastic. A marginal increase of the price of traditional brand will result in a huge decrease in the quantity demanded for that seed brand. The savings can be used to purchase other varieties of sorghum seed. Alternatively authorities could subsidize the price of preferred sorghum seeds or any drought resistant seed. The government can also introduce policies and incentives to farmers who grow new small drought resistant crops in semi-arid and arid regions. Such incentives could be in form of tax rebates or shows where winners would walk away with prizes. The government through financial institutions such the land bank or commercial banks can provide credit facilities to farmers. With the Zimbabwean's ongoing land reform, the government should consider allocating optimal farms to new farmers who are in semi-arid and arid areas of Zimbabwe. With more land a farmer will have space to grow both existing and new varieties small grain crops. In conclusion this study established that in the face of changing climate, introducing new crop varieties in semiarid and arid regions could result in more food security and increase in farmers' welfare. However, it is of great importance to identity key determinants of choosing crop variety.

\section{REFERENCES}

[1] Adams RM, (1989). Global climate change and agriculture: An economic perspective. American Journal of Agricultural Economics 71(5): 1272-79.

[2] Alexandrov VA \& Hoogenboom G, (2000). The impact of climate variability and change on crop yield in Bulgaria. Agriculture and Forest Meteorology 104: 315-27.

[3] Assan, J. K. and Kumar, P. (2009) Livelihood options for the poor in the changing environment Journal of International Development J. Int. Dev. 21, 393-402.

[4] Barron EJ, (1995). Climate models, how reliable are their predictions? Consequences. http://www.gcrio.org/consequences/fall95/mod.html

[5] Benhin, JKA, (2006). Climate change and South African agriculture: Impacts and adaptation options. CEEPA Discussion Paper No. 21. Centre for Environmental Economics and Policy in Africa, University of Pretoria.

[6] Biermann, F., (2007). 'Earth system governance as a crosscutting theme of global change research. Global Environmental Change.

[7] Carney, D (1999): Approaches to Sustainable Livelihoods for the Rural Poor, ODI Poverty Briefing, 2. Chambers, R and R. Conway (1992): 'Sustainable Rural Livelihoods: Practical Concepts for the 21st Century', IDS Discussion Paper No. 296; Brighton: Institute of Development Studies.

[8] Chang C, (2002). The potential impact of climate change on Taiwan's agriculture. Agricultural Economics 27: 51-64.

[9] Davies J, Bennett R. (2007). Livelihood adaptation to risk: constraints and opportunities for pastoral development in Ethiopia's afar region. Journal of Development Studies 43(3): 490-511.

[10] Deke O, Hooss K.J, Kasten C and Springer K, (2001). Economic impact of climate change: Simulations with a regionalized climate-economy model. Kiel working paper No. 1065, Kiel Insitute of World Economics, Kiel. http://www.ideas.repec.org/p/wop/kieliw/1065.html 
[11] Deschenes, Oliver, and Michael Greenstone. (2007). "The Economic Impacts of Climate Change: Evidence from Agricultural Output and Random Fluctuations in Weather", American Economic Review 97(1): 354-385.

[12] Dinar A. and Beach H, (1998). The climate sensitivity of Indian agriculture. In Dinar A et al. (eds), 1998. Measuring the Impact of Climate Change on Indian Agriculture. World Bank Technical paper 402. Washington, DC.

[13] Dinar A. et al. (eds), (1998). Measuring the Impact of Climate Change on Indian Agriculture. World Bank Technical paper 402. Washington, DC.

[14] Dinar, A, Hassan, R, Mendelsohn, R and Benhin, J, (2008). Climate change and agriculture in Africa: impact assessment and adaptation strategies. Earth Scan, London.

[15] Du Toit MA, Prinsloo S and Marthinus A, (2001). El Niño-southern oscillation effects on maize production in South Africa: A preliminary methodology study. In Rosenzweig C, Boote KJ, Hollinger S, Iglesias A \& Phillips JG (eds), Impacts of El Niño and climate variability on agriculture. ASA Special Publication 63, American Society of Agronomy, Madison, Wis., USA, pp. 77-86.

[16] FAO (Food and Agriculture Organization), (1996). Agro-ecological zoning: Guidelines, FAO Soils Bulletin 73. Rome, Italy.

[17] GoK (2003): Economic Recovery Strategy for Wealth and Employment Creation (ERS 2003-2007). June 2003.

[18] GOK (2007). Vision 2030. A competitive and prosperous Kenya .A summary document produced by the GOK. July 2007.

[19] Green, W.H., 2000. Econometric Analysis, 4th ed. Prentice-Hall, Upper Saddle River, NJ.

[20] Hausman, J. and McFadden, D, (1984). Specification tests for the multinomial logit model. Econometrica 52 (5), 1219-40.

[21] Hausman, J and Wise, D, (1978). A conditional probit model for qualitative choice: Discrete decisions recognizing interdependence and heterogeneous preferences. Econometrica 46,403-26.

[22] Hassan, R., Nhemachena, C., (2008). Determinants of African farmers' strategies for adapting to climate change: multinomial choice analysis. African Journal of Agricultural and Resource Economics 2 (1), 83-104.

[23] IPCC (Intergovernmental Panel on Climate Change). (2007a). The Physical Science Basis, Cambridge University Press, Cambridge UK.

[24] IPCC (Intergovernmental Panel on Climate Change). (2007b). Impacts, Adaptation and Vulnerability, Cambridge University Press, Cambridge UK.

[25] Joint Nature Conservation Committee (JNCC) (2008) Adapting to climate change: opportunities and priorities for biodiversity conservation. JNCC.

[26] Kandlinkar, M and Risbey, J, (2000). Agricultural impacts of climate change: If adaptation is the answer, what is the question? Climatic Change 45, 529-39.

[27] Kaiser HM, Riha S.J, Wilks D.S, Rossiter D.G. and Sampath RK, (1993). A farm-level analysis of economic and agronomic impacts of gradual warming. American Journal of Agricultural Economics 75: 387-98.

[28] Kelly, D.L., Kolstad, C. D., and G.T. Mitchell. 2005. "Adjustment costs from environmental change" Journal of Environmental Economics and Management 50: 468495.

[29] Kiteme B.P. (2009). Agricultural Extension Services and Adaptation to Climate Change in Kenya. Draft Report. German Development Institute Bonn, Germany.

[30] Kurukulasuriya, P. and Mendelsohn, R, (2006a). A Ricardian analysis of the impact of climate change on African cropland. CEEPA Discussion Paper No. 8. Centre for Environmental Economics and Policy in Africa, University of Pretoria.

[31] Kurukulasuriya, $P$ and Mendelsohn, R, (2006c). Crop selection: adapting to climate change in Africa. CEEPA Discussion Paper No. 26. Centre for Environmental Economics and Policy in Africa. University of Pretoria. 
[32] Kurukulasuriya, P., R. Mendelsohn, R. Hassan, J. Benhin, M. Diop, H. M. Eid, K.Y. Fosu, G. Gbetibouo, S. Jain, , A. Mahamadou, S. El-Marsafawy, S. Ouda, M. Ouedraogo, I. Sène, N. Seo, D. Maddison and A. Dinar. (2006). "Will African Agriculture Survive Climate Change?" World Bank Economic Review 20: 367-388.

[33] Lal M., et al., (1999). Growth and yield responses of soybean in Madhya Paradesh, India, to climate variability and change. Agriculture and Forest Meteorology 93(1): 5370.

[34] Mabugu R, (2002). The use of CGE modeling in the analysis of environmental policy reform. Collaborative Regional Masters in Environmental Economics and Policy (CEEPA) Specialization Course Module. Lecture notes. University of Pretoria, South Africa.

[35] McCarthy, J. James, Martello, L. Marybeth, (2004), Climate Change in the Context of Multiple Stressors and. Resilience. ACIA Scientific Report, Cambridge University Press, p. $945-983$.

[36] Maddison, D., (2006). The perception of and adaptation to climate change in Africa. CEEPA. Discussion Paper No. 10. Centre for Environmental Economics and Policy in Africa. University of Pretoria, Pretoria, South Africa.

[37] Maldives L. (2001). Initial National Communication to the United Nations Framework Convention on Climate Change. http://unfccc.int/resource/docs/natc/maldnc1.pdf.

[38] Mano, R and Nhemachena C, (2006). Assessment of the economic impacts of climate change on agriculture in Zimbabwe: A Ricardian approach. CEEPA Discussion Paper No. 11. Centre for Environmental Economics and Policy in Africa, University of Pretoria.

[39] Mendelsohn R., Nordhaus W., and Shaw D., (1994). The impact of global warming on agriculture: A Ricardian analysis. American Economic Review 84: 753-71.

[40] Mendelsohn R., and Tiwari D., (2000). Two essays on climate change and agriculture: A developing country perspective. FAO Economic and Social Development Paper 145. Rome, Italy.

[41] Mendelsohn, Robert, Ariel Dinar, and Apurva Sanghi. (2001). "The Effect of Development on the Climate Sensitivity of Agriculture", Environment and Development Economics 6: 85-101.

[42] Nobre C., A., Oyama M., D., Oliveira G S, Marengo J., A., Salati E. (2004). Impact of climate change scenarios for 2100 on the biomes of South America. First International CLIVAR Conference. Baltimore, USA. 21-25 June 2004.

[43] Nordhaus, W., D., and Yang Z., (1996). A regional dynamic general-equilibrium model of alternative climate change strategies. American Economic Review 86(4): 711-63.

[44] Nyong A (2006) Capacity Needs Assessments for Climate Change Adaptation Support Programme for Action Research and Capacity Development in Africa (CCAA). DFID.

[45] Obunde Paul, Joseph M. Maitima, and Jennifer Olson. Adaptation to Climate Change: (2007). A Case of Kenya. Climate Land Interactions Project working paper 63 pages

[46] Oladosu G, Shortle J., Lazo J.K and Alber D, (1999). Valuation of climate change in computable general equilibrium models. http://www.soc.uoc.gr

[47] Oxfam (2006). Causing Hunger: An Overview of the Food Crisis in Africa. Briefing Paper. 39 pp. http://www.oxfam.org/en/policy/briefingpapers/bp91_africa_food_crisis.

[48] Oxfam (2007). Adapting to Climate Change: What's Needed in Poor Countries, and Who Should Pay. Oxfam Briefing Paper 104. Oxfam International Secretariat. Oxford, UK. 47 pp.

[49] Parry, M.L., Rosenzweig, C., Iglesias, A., Livermore, M., Fischer, G. (2004). Effects of climate change on global food production under SRES emissions and socio-economic scenarios. Global Environmental Change, Vol. 14: 53-67.

[50] Polsky C., and Esterling W.E, (2001). Adaptation to climate variability and change in the US Great Plains: A multi-scale analysis of Ricardian climate sensitivities. Agriculture, Ecosystem and Environment 85(3): 133-44.

[51] Reilly J, Hohmann N \& Kane S, (1994). Climate change and agricultural trade: Who benefits, who loses? Global Environmental Change 4(1): 24-36. 
[52] Reilly, J., W. Baethgen, F. Chege, S. van de Geijn, L. Enda, A. Iglesias, et al. (1996). Agriculture in a changing climate: impacts and adaptations. p. 427- 468. In Watson, R., M. Zinyowera, R. Moss, and D. Dokken (eds.) Climate Change 1995: Intergovernmental Panel on Climate Change Impacts, Adaptations, and Mitigation of Climate Change. Cambridge University Press, Cambridge, UK.

[53] Rosenzweig C, (1989). Global Climate Change: Predictions and Observations. American Journal of Agricultural economics 71(5): 1265-71.

[54] Rosenzweig, C., and D. Liverman. (1992). Predicted effects of climate change on agriculture: A comparison of temperate and tropical regions. In Global climate change: Implications, challenges, and mitigation measures, ed. S. K. Majumdar, 342-61. PA: The Pennsylvania Academy of Sciences.

[55] Rosenzweig M, Strzepek K, Hillel D, Iglesias A, Yates D \& Holt A, (1998). Water for agriculture: Today, 2010 and 2020. International Food Policy Research Institute, Washington DC. Sadoulet E and De Janvry A, 1995. Quantitative Development Policy Analysis. London: John Hopkins University Press.

[56] Seo, Niggol, Robert Mendelsohn, and Mohan Munasinghe. (2005). "Climate Change and Agriculture in Sri Lanka: A Ricardian Valuation", Environment and Development Economics 10: 581-596.

[57] Seo, N and Mendelsohn, R, (2006a). Climate change impacts on animal husbandry in Africa: A Ricardian analysis. CEEPA Discussion Paper No. 9. Centre for Environmental Economics and Policy in Africa, University of Pretoria.

[58] Seo, N and Mendelsohn, R, (2006b). Climate change adaptation in Africa: A microeconomic analysis of livestock choice. CEEPA Discussion Paper No. 19. Centre for Environmental Economics and Policy in Africa, University of Pretoria.

[59] Seo, S. N. and R. Mendelsohn (2008b). "An Analysis of Crop Choice: Adapting to Climate Change in South American Farms", Ecological Economics.

[60] Seo, N., Mendelsohn, R., (2008). Animal husbandry in Africa: climate change impacts and adaptations. African Journal of Agricultural and resource Economics 2 (1), 65-82.

[61] Southworth $\mathrm{J}$ et al., (2000). Consequences of future climate change and changing climate variability on maize yield in the Midwestern United States. Agriculture, Ecosystem and Environment 82(3): 139-58.

[62] Swart R, Robinson J, Cohen S (2003) Climate change and sustainable development: expanding the options. Climate Policy 3S1:S19-S40.

[63] Tse, YK, (1987). A diagnostic test for the multinomial logit model. Journal of Business and Economic Statistics 5 (2), 283-86.

[64] UNDP and Government of Kenya (2008) Adapting to Climate Change in Arid and SemiArid Lands. United Nations Development Programme.

[65] UNEP/GRID-Arendal (2005). Climate change: processes, characteristics and threats. UNEP/GRID-Arendal Maps and Graphics Library.

[66] USAID (2007) Adapting to climate variability and change a guidance manual for development planning. USAID.

[67] Washington, W., J. Weatherly, G. Meehl, A. Semtner, T. Bettge, A. Craig, W. et al. (2000). Parallel climate model (PCM): Control and transient scenarios. Clim. Dynam. 16:755-774.

[68] Wigley, T.M.L. (1999). The Pew Center on Global Climate Change. The Science of Climate Change: Global and U.S. Perspectives.

[69] Winter P, Muragi R., Sadoulet E and DeJanvry A., (1996). Climate change, agriculture, and developing economies. Department of Agricultural and Resource economics, Division of Agriculture and Resource Economics. University of California at Berkley. Working paper No. 785.

[70] Wu, J and Babcock, BA, (1998). The choice of tillage, rotation, and soil testing practices: Economic and environmental implications. American Journal of Agricultural Economics 80, 494-511.

[71] World Bank, (2003). Africa Rainfall and Temperature Evaluation System. World Bank, Washington, DC. 